\title{
Ergenlerde Okul Tükenmişliğinin Yordayıcısı Olarak Akademik Kontrol Odağı
}

\section{Academic Locus of Control as a Predictor of School Burnout in Adolescents}

\author{
Gürcan ŞEKER**, Yasemin Yavuzer***
}

\begin{abstract}
Öz: $\mathrm{Bu}$ araştırmanın temel amacı ergenlerde okul tükenmişliğinin akademik kontrol odağı ve bazı demografik değişkenler açısından incelenmesidir. Araştırma verileri İç Anadolu bölgesinde yer alan bir il merkezinde beş lisede 9-12.sınıflarda öğrenim görmekte olan 701 öğrenciden toplanmıştır. Araştırmada "Ortaöğretim Okul Tükenmişlik Ölçeği” ve "Akademik Kontrol Odağı Ölçeği” kullanılmıştır. Verilerin çözümlenmesinde gruplar arası farklllığı belirlemek için Bağımsız Gruplar t Testi ve Tek Faktörlü Varyans Analizi, okul tükenmişliğini yordayan değişkenlerin belirlenmesi için hiyerarşik regresyon analizi kullanılmıştır. Araştırma sonucunda; cinsiyet, okul türü, algılanan ders başarısı, sınıf düzeyi, annebaba eğitim düzeyi, devamsızlık süresi ve günlük ders çalışma süresi değişkenlerine göre okul tükenmişliğinin bir ya da birden fazla alt boyutundan elde edilen puanlarda anlamlı bir fark olduğu gözlenmiştir. Bunun yanında okul tükenmişliği alt boyutları ile içsel kontrol odağı arasında orta düzeyde ve negatif yönde, okul tükenmişliği alt boyutları ile dışsal kontrol odağı arasında orta düzeyde ve pozitif yönde bir ilişsinin olduğu görülmüştür. Diğer yandan regresyon analizi sonuçlarına göre; akademik kontrol odağı içsel ve dışsal kontrol boyutları demografik değişkenlerle birlikte okul tükenmişliğinin okula karşı ilgi kaybı alt boyutunun \%12'sini, ders çalışmaktan tükenme alt boyutunun \%15'ini, aileden kaynaklı tükenme alt boyutunun \%15'ini, ödev yapmaktan tükenme alt boyutunun \%14'ünü, öğretmen tutumlarından bunalma ve sıkılma alt boyunun \%17'sini ve okulda yetersizlik alt boyutunun \%11'ini açıklamaktadır. Okul psikolojik danışma hizmetleri çerçevesinde öğrenci tükenmişliğine ilişkin koruyucu ve önleyici çalışmalar planlanırken öğrencilere içsel denetim kazandıracak etkinliklere yer verilmelidir. Anahtar Kelimeler: Okul tükenmişliği, akademik kontrol odağı, ergenler
\end{abstract}

\begin{abstract}
The purpose of this study is to examine school burnout in adolescents in terms of academic locus of control and some demographic variables. The data were collected from 701 of students 9-12 grade at five high schools in a province center located in the Central Anatolia region. "Secondary School Burnout Scale" and "Academic Locus of Control Scale" were used in the study. Independent samples ttest and one-factor analysis of variance were used for determining the differences between groups, and hierarchical multiple regression analysis for determining variables predicting school burnout. Study results show that there was a significant difference in the scores obtained from one or more subdimensions of school burnout according to sex, school type, achievement, grade level, parents' education levels, absenteeism and daily study duration variables. Also, there was a medium level and positive relationship between the school burnout sub-dimensions and internal locus of control, and between the school burnout sub-dimensions and external locus of control. Furthermore, internal and external control dimensions of academic locus of control with demographic variables explain $12 \%$ of loss of interest towards school, $15 \%$ of burnout from studying, $15 \%$ of burnout due to family, $14 \%$ of burnout from doing homework, $17 \%$ of burnout due to teachers and $11 \%$ of school inefficacy sub-dimensions of school burnout. While school counseling and psychological services plan protective and preventive works regarding student burnout, they should also make activities that will give students internal control.
\end{abstract}

Keywords: School burnout, academic locus of control, adolescents

*Bu makale 07-09 Ekim 2015 tarihleri arasında Mersin'de düzenlenen “13.Ulusal Psikolojik Danışma ve Rehberlik Kongresi”nde sunulan sözlü bildirinin genişletilmiş halidir.

**Araş. Gör., Niğde Ömer Halisdemir Üniversitesi, Eğitim Fakültesi, Niğde-Türkiye, e-posta: gurcanseker@ohu.edu.tr

*** Doç. Dr., Niğde Ömer Halisdemir Üniversitesi, Eğitim Fakültesi, Niğde-Türkiye, e-posta: yyavuzer@hotmail.com 


\section{Giriş}

OECD ülkelerinde temel eğitimin birinci kademesindeki öğrenciler, ortalama olarak yılda 804 saat olarak planlanan öğretim saati görmektedir. İkinci kademedeki öğrencilerin birinci kademedekilere göre yılda yaklaşık 112 saat daha fazla öğretim saati görmeleri planlanmaktadır (OECD, 2015). Buna 14 yaş ve üzeri süreci kapsayan ortaöğretim dönemi eklendiği zaman okulda geçirilen sürenin bireyin yaşamının önemli bir oranını kapsadığı düşünülmektedir. Ülkemiz açısından da durum aynıdır ancak ülkemizde öğrenci nüfusundaki yoğunluk ve farklı eğitim dönemlerinde (ortaokul ve lise) öğrencileri bekleyen sinav maratonunu hesaba kattığımızda, bu durumun ögrenciler üzerinde yarattığı stres ve buna bağlı olarak oluşan tükenmişliğin göz ardı edilemeyeceği ortadadır. Tükenmişlik, bir yangında boğulma ya da bir mumun sönmesi gibi, bitkin düşme durumunu tanımlayan bir metafordur. Tükenmişliğin sözlük tanımı; başarısızlık, yorgunluk, enerji, güç ya da kaynakların aşırı derecede azalması şeklinde yapılabilir (Schaufeli, 1999). Tükenmişlik kavramı ilk olarak Freudenberger (1974) tarafindan ortaya atılan bir kavram olsa da, zaman içerisinde yukarıda olduğu gibi birbirine benzer birçok tanımı yapılmıştır (aktaran Maslach, Schaufeli ve Leiter, 2001). Tükenmişlik konusu ile ilgili yoğun olarak çalışan Maslach ve Jackson (1981), tükenmişliğin her ne kadar iş ve meslek hayatı ile ilgili olsa da, kişinin günlük yaşamında da bazı problemlere yol açan bir durum olduğunu belirtmiş̧lerdir. Bu nedenle araştırmacılar iş yaşamında tükenmişliği ölçmek amacıyla bir ölçme aracı geliştirmişler ve tükenmişliği, "duygusal tükenme, duyarsızlaşma ve kişisel başarı hissinde azalma" şeklinde, üç boyuttan oluşan bir sendrom olarak tanımlamışlardır.

Schaufeli, Martinez, Marques-Pinto, Salanova ve Bakker'in (2002) Maslach Tükenmişlik Envanteri’nin öğrenci formunu oluşturmak amacıyla psikometrik çalışmalar yürütmesiyle birlikte, okul-öğrenci tükenmişliği alanındaki çalışmalara ilgi artmıştır. Böylece genel olarak iş ve meslek alanında yoğun olarak çalışılan tükenmişlik kavramı, son zamanlarda öğrenciler üzerinde çalış1lan bir kavram haline gelmiştir (Aypay ve Eryılmaz, 2011; Çapri, Özkendir, Özkurt ve Karakuş, 2012; Gan, Shang ve Zhang, 2007; Luo, Wang, Zhang, Chen ve Quan 2016; May, Bauer ve Fincham, 2015; Parker ve Salmela-Aro, 2011; Salmela-Aro ve Tynkkynen, 2012; Yang, 2004). Okul tükenmişliği, öğrencilerin okul yaşamı ile ilgili özyeterlik sorunu ve öğrencinin kendine ilişkin beklentileri ile ailesi, arkadaşları gibi yakın çevresinin ona ilişkin beklentileri arasındaki uyumsuzluktan doğmaktadır (Schaufeli ve diğerleri, 2002). Başka bir deyişle okul tükenmişliği, okulun ve eğitim sürecinin "aşırı taleplerinin" öğrencide yarattı̆̆ yıpranma ve bitkin düşme durumunu ifade etmektedir (Aypay ve Eryılmaz, 2011). Slivar (2001), okul yaşamına ilişkin tükenmişliğin; okulun ağır taleplerinin, kontrol kaybının, yüksek başarı için gerekli olan donanım ve motivasyon yoksunluğunun, kişilerarası ilişkilerde yaşanan sıkıntıların ve öğrenci için önemli olan öğretmen ve aile üyeleri gibi kişilerin yüksek beklentilerinin bir sonucu olarak ortaya çıktığını belirtmektedir.

Kontrol odağ 1 kavramı ise, sosyal öğrenme kuramı çerçevesinde yapılandırılmış ve bir kişilik özelliği olarak tanımlanarak ilk kez Rotter tarafından kullanılmıştır. Kontrol odağı, bireylerin elde ettikleri sonuçların veya ödüllerin, ya da başarı veya başarısızlık durumlarına ilişkin beklentileridir. $\mathrm{Bu}$ beklentiler, kendileri dışındaki şans, kader vb. faktörlere bağlanabileceği gibi, kendi davranışlarının bir sonucuna da bağlanabilmektedir (Yeşilyaprak, 2004). Kişinin sahip olduğu beklentiler ile elde edilen sonuçlar arasındaki fark bir gerilime yol açacaktır. Bu gerilim tükenmişliğe neden olur (Rotter, 1982, aktaran Sürgen, 2014). Aradaki fark ne kadar büyük ise gerilimin yaratacağı etki de tükenmişlik üzerinde o kadar farklı olacaktır. Gerilim, içten denetimlileri bu durumu değiştirmeye yönelik arayışlara iteceği için zamanla kişiler bu gerilimle başa çıkmayı öğrenir. Dıştan denetimlilerde ise gerilim, kişiyi çaresizliğe sürükleyecektir (Meier, 1984, aktaran Sürgen, 2014). Stres ile başa çıkabilme ve beklentiler açısından içten ve dıştan kontrollü bireyler farklılaşmaktadır ve farklı düzeylerde tükenmişlik yaşamaktadırlar. İlgili araştırmalarda tükenmişlik, dışsal kontrol odaklı olan bireylerde, içsel kontrol odaklı olan bireylere kıyasla daha yüksek olduğu bulunmuştur (Sarıkaya, 2007; Sürgevil, 2006). Sürgen (2014), kontrol odağ1 ve tükenmişlik düzeyi alt boyutu olan duygusal tükenme arasında istatistiksel olarak anlamlı bir ilişki olduğu ancak açıklayıcılık gücünün zayıf olduğunu bulmuştur. 
Ergenlik dönemi fiziksel, sosyal ve psikolojik değişimlerin oldukça hızlı yaşandığ 1 bir dönemdir. Gençlerin ve ergenlerin birçoğu yaşamlarının bu evresinde kendine özgü değişiklik ve geçişlere uyum sağlama konusunda zorlanmakta, birçok problem yaşamaktadır. Tüm bunların sonucunda ergenlerin bir kısmı, depresif semptomlar ve okulla ilgili tükenmişlik gibi çeşitli psikolojik sıkıntılarla baş etmek durumunda kalabilmektedir (Salmela-Aro, Savolainen ve Holopainen, 2009). İlgili yazında okul-öğrenci tükenmişliği ile ilgili çalışmalara bakıldığında; öğrencilerin tükenmişlik düzeyinin cinsiyete göre farklılaştı̆̆ını ortaya koyan birçok çalışma yer almaktadır. Bu çalışmaların çoğunda erkeklerin okul tükenmişliği puanlarının kız öğrencilere göre daha yüksek olduğu görülürken (Aypay ve Sever, 2015; Çapulcuoğlu ve Gündüz, 2013; Öztan, 2014; Salmela-Aro, Kiuru ve Nurmi, 2008; Seçer ve Gençdoğan, 2012; Sever ve Aypay, 2011), bazılarında ise okul tükenmişliği puanlarında kız öğrenciler lehine artış olduğu görülmektedir (Acar ve Çakır, 2015; Salmela-Aro ve Tynkkynen, 2012). Bunun yanında akademik başarı ve okul tükenmişliği arasında (Aypay ve Sever, 2011; Çapulcuoğlu ve Gündüz, 2013; E. Duru, S. Duru ve Balk1s, 2014; Kiuru, Aunola, Nurmi, Leskinen ve Salmela-Aro, 2008; Yang, 2004) ve öznel iyi oluş ile okul tükenmiş̧liği arasında (Raiziene, PilkauskaiteValickiene ve Zukauskiene, 2014) negatif yönde anlamlı bir ilişki olduğunu ortaya koyan çalışmalar yer almaktadır. Literatürdeki diğer çalışmalar ise; pozitif okul ve sınıf ikliminin okul tükenmişliği üzerinde etkili olduğunu (Pilkauskaite-Valickiene, Zukauskiene ve Raiziene, 2011; Salmela-Aro, Kiuru, Pietikïnen ve Jokela, 2008), sosyal desteğin okul tükenmişliğini anlamlı olarak yordadığını (Çam, Deniz ve Kurnaz, 2014; Jacobs ve Dodd, 2003; Kutsal ve Bilge, 2012) ve lise öğrencilerinin okula ilgi kaybı ve ödev yapmaktan tükenme düzeyleri yükseldikçe derse katılmaya motive olma düzeylerinin düştüğünü (Aypay ve Eryılmaz, 2011) ortaya koymaktadır. Dolayısıyla okul tükenmişliği ile çeşitli değişkenler birlikte çalışılmıştır. Ancak okul tükenmişliği ile akademik kontrol odağının, Aypay'ın (2011) ölçeğini geliştirirken benzer ölçek geçerliliği için kullanması dışında, birlikte çalışılmadığı göze çarpmaktadır. Psikolojik danışma ve rehberlik alanının önleyici ve koruyucu ruh sağlığı işlevi göz önünde bulundurulduğunda, öğrencilerdeki okul tükenmişliği konusunda yapılacak araştırmalar daha da önemli hale gelmektedir. Çünkü konu ile ilgili araştırma bulgularının okul psikolojik danışma hizmetleri çerçevesinde okul tükenmişliğine ilişkin koruyucu ve önleyici müdahalelere yol göstereceği düşünülmektedir. $\mathrm{Bu}$ araştırmada, ergenlerde okul tükenmişliği ile akademik kontrol odağı arasındaki ilişki incelenmiştir. Bu genel amaç çerçevesinde şu sorulara yanıt aranmıştır: (a) Ergenlerin okul tükenmişliği alt ölçek puanları demografik değişkenlere (okul türü, cinsiyet, sınıf düzeyi, anne-baba eğitim düzeyi, okul devamsızlığı, algılanan akademik başarı ve günlük düzenli ders çalışma saati) göre değişmekte midir? (b) Ergenlerin okul tükenmişliğini akademik kontrol odağ 1 yordamakta mıdır?

\section{Yöntem}

$\mathrm{Bu}$ araştırma lise öğrencilerinde okul tükenmişliğinin akademik kontrol odağı ile ilişkisini incelemeyi amaçlayan ilişkisel modelde bir çalışmadır. En yalın tanımıyla ilişkisel araştırmalar en az iki değişken arasındaki ilişkinin incelendiği çalışmalardır (Christensen, Johnson ve Turner, 2014).

\section{Çalışma Grubu}

Araştırma, İç Anadolu bölgesinde yer alan bir il merkezinde Anadolu, Meslek ve Fen Liselerinden oluşan beş lisede öğrenim gören toplam 3511 öğrenciden tabakalı örnekleme yoluyla seçilmiş 701 öğrenci ile yürütülmüştür. Tabakalı Örnekleme, ana kütleyi oluşturan birimlerin incelenecek özellikleri bakımından farklılık göstermesi durumunda benzer özelliklere sahip birimlerin " tabaka" adı verilen alt gruplarda toplandığ 1 ve örneklemin, her tabakadan ayrı ayrı basit tesadüfi örnekleme yöntemi ile seçilen örneklemlerin birleştirilmesiyle oluşturulduğu bir örnekleme yöntemidir (Balc1, 2006, s. 85). Bu çalışmada hem liselerdeki hem de sınıf düzeylerindeki öğrenci sayılarının farklı olması nedeniyle tabakalı örnekleme yöntemi kullanılmıştır. Lise türlerine ve sınıf düzeylerine göre tabakalar oluşturulmuş sonra her tabakadan basit tesadüfi örnekleme yöntemiyle örneklem oluşturulmuştur. Öğrencilerin \% 48'i 
k1z, \% 52'si erkektir. Öğrencilerin \%37.2'si Anadolu, \%29.2'si Meslek, \%33.5'i Fen lisesinde; $\%$ 27,8'i 9.sinıfta, \% 27,2'si 10.sinıfta, \% 26,7'si 11.sinıfta ve \% 18,3'ü 12.sinıfta öğrenim görmektedir.

\section{Veri Toplama Araçları}

Veri toplama aracı olarak Aypay (2011) tarafindan geliştirilen Ortaöğretim Okul Tükenmişliği Ölçeği ile Akın (2007) tarafından geliştirilen Akademik Kontrol Odağı Ölçeği kullanılmıştır.

Ortaöğretim Okul Tükenmişliği Ölçeği (OOTÖ): Ortaöğretim Okul Tükenmişliği Ölçeği OOTÖ Aypay (2011) tarafindan geliştirilmiştir. OOTÖ, 34 maddeden oluşmakta ve dörtlü dereceleme (4= Tamamen katılıyorum, 3= Katılıyorum, 2= Katılmıyorum, 1= Hiç katılmıyorum) biçiminde yanıtlanmaktadır. OOTÖ'nün alt faktörlerinin her birinden alınan puanın yüksek olması o faktör boyutunda tükenmişliğin yüksek olduğu anlamına gelmektedir. OOTÖ'nün geçerlik ve güvenirlik çalıșması Siirt, Bursa, İzmir ve Eskișehir illerinde bulunan 14 ortaöğretim okulunda öğrenimine devam eden, dört sınıf düzeyinden toplam 728 öğrenci üzerinde gerçekleştirilmiştir. OOTÖ'nün yap1 geçerliği için hem Açımlayıcı Faktör Analizi hem de Doğrulayıcı Faktör Analizi yapılmıştır. AFA sonucu, özdeğerleri 1'den büyük yedi faktörlü bir yap1 ortaya çıkmıştır. Yedi faktörün açıkladıkları toplam varyans \% 61'dir. Yedi faktördeki maddelerin faktör yük değerleri .47 ile .86 arasındadır. Faktörlere içerdikleri maddelerin vurguladıkları anlamlara uygun olarak "Okula İlgi Kaybı" (OİK), "Ders çalı̧̧maktan Tükenme" (DÇT), "Aileden Kaynaklı Tükenmişlik" (AKT), "Ödev Yapmaktan Tükenme" (ÖYT), "Öğretmen Tutumlarından Bunalma ve Sıkılma" (ÖTBS), "Dinlenme ve Eğlenme Gereksinimi" (DEG) ve "Okulda Yetersizlik" (OY) isimleri verilmiștir. AFA ile belirlenen ölçeğin yedi faktörlü yapısının toplanan verilerle ne derece uyum gösterdiğine ilişkin ek kanıtlar elde etmek amaciyla DFA uygulanmıştır. Modele ait diğer uyum iyiliği indeksleri model-veri uyumunun iyi olduğunu göstermiştir. OOTÖ'nün toplamı ve alt faktörleri için hesaplanan Cronbach Alpha iç tutarlılık katsayıları .67 ile .92 arasında değișmektedir. OOTÖ'nün iki-yarı arasındaki korelasyonu da .88'dir (Aypay, 2011). Aypay ve Eryılmaz (2011) farklı bir çalışma grubundan toplanan veriler üzerinde OOTÖ’nün güvenirliği ve faktör yapısını yeniden incelemişlerdir. Ölçek üzerinde gerçekleştirilen AFA sonuçlarına göre, yedi faktörlü ölçeğin açıklanan varyansı \%63.49 bulunmuştur. Ayrıca ölçek bütünü için hesaplanan Cronbach Alpha güvenirlik katsayısı .91 'dir. Ölçek alt faktörleri için hesaplanan iç tutarlılık katsayıları .70 ile .86 arasında değişmektedir $\mathrm{Bu}$ çalışma kapsamında ölçeğin bütünü için iç tutarlık katsayısı .89 , alt boyutlar için sirasılyla $.88, .86, .80, .82, .82, .75$ ve .73 'dür.

Akademik Kontrol Odağ Ölçeği (AKOÖ): Akın (2007) tarafından geliştirilen AKOÖ yetişkin kişilerin akademik kontrol odağ 1 düzeylerini belirlemeye yönelik 17 maddeden oluşan 5'li ("1" Hiç uygun değil, "2" Uygun değil, "3" Kararsızım, "4" Oldukça uygun ve "5" Tamamen uygun) Likert tipi bir derecelendirme sunmaktadır. Ölçek akademik dışsal kontrol odağı ile akademik içsel kontrol odağı olmak üzere iki alt boyuttan oluşmaktadır. İçsel akademik kontrol odağı alt ölçeğinden alınabilecek en yüksek puan 30, en düşük puan ise 6'dır. Dışsal akademik kontrol odağ1 alt ölçeğinden alınabilecek en yüksek puan 55, en düşük puan ise 11'dir. Yapılan açımlayıcı faktör analizi sonucu ölçeğin faktör yüklerinin .61 ile .95 arasında değiştiği gözlenmiştir. İki boyutlu akademik kontrol odağı modelinin doğrulanması amaciyla 695 üniversite öğrencisinden elde edilen verilere uygulanan doğrulayıcı faktör analizi sonucu ölçeğin iki boyutta iyi uyum verdiği bulunmuştur. Ölçeğin Cronbach alfa iç tutarlılık güvenirlik katsayısı akademik içsel kontrol odağı için .94 ve akademik dışsal kontrol odağı için .95 olarak bulunmuştur. Ölçeğin test-tekrar test güvenirlik katsayıları ise akademik içsel kontrol odağ için .97 ve akademik dışsal kontrol odağ $\breve{1}_{\text {için }} .93$ olarak bulunmuştur (Akın, 2007). Ölçeğin ergen formunun uyarlaması Sarıçam (2014) tarafından yapılmış ve uyarlama çalışmasından elde edilen bulgular 17 maddelik ölçeğin ergenlerin akademik kontrol odaği düzeylerini geçerli ve güvenilir bir şekilde ölçmek amacıyla kullanılabileceğini göstermiştir. Bu çalışma kapsamında 
ölçeğin iç tutarlık katsayısı akademik içsel kontrol odağ 1 için .82 ve akademik dışsal kontrol odağ 1 için .75 olarak bulunmuştur.

\section{İşlem}

Veriler beş lisede öğrenim gören ergenlerin kendi sınıflarında ve rehberlik saatlerinde toplanmıştır. Araştırmacı tarafindan araştırmanın amacına ilişkin kısa bir bilgi verildikten sonra gönüllü olan öğrencilere ölçekler uygulanmıştır. Öğrencilere verdikleri yanıtların gizli tutulacağı söylenmiş ve samimi yanıt vermeleri istenmiştir. Ölçeklerin uygulanması yaklaşık olarak 15-20 dakika sürmüştür.

\section{Verilerin Analizi}

Veri analizleri SPSS 18 programı ile gerçekleştirilmiştir. Gruplar arası farklılığı belirlemek için Bağımsız Gruplar t Testi ve Tek Faktörlü Varyans Analizi, farklılıkların kaynağını test etmek için "Tukey testi", değişkenler arasındaki ilişkileri belirlemek için Pearson Momentler Çarpımı Korelasyon analizi, okul tükenmişliğini yordayan değişkenlerin belirlenmesi için Hiyerarşik Regresyon Analizi kullanılmıştır. Analiz yapılmadan önce çoklu hiyerarşik regresyon analizinin varsayımları test edilmiştir. Verilerin normal dağılıma uygunluğu çarpıklık ve basıklık değerleri incelenerek test edilmiştir. OOTÖ ve AKOÖ alt ölçeklerinden elde edilen puanların dağılımı tüm bağımsız değişkenler için çarpıklık ve basıklık değerleri açısından incelenmiştir. Çarpıklık değerleri -.03 ile .69 arasında, basıklık değerleri de -.93 ile 1.92 arasında değişmektedir. Basıklık ve çarpıklık katsayılarının ideal olarak +1 ve -1 arasında olmasının arzulandığı, ancak +2 ve -2 arasındaki değerlerin de kabul edilebilir olduğu belirtilmektedir (Karaatl1, 2006). Dolayısıyla puanların normalden aşırı sapma göstermediği söylenebilir. Değişkenler arasındaki ikili korelasyonların -.02 ile .53 arasında olması değişkenler arası çoklu bağlantının olmadığını göstermektedir. Ayrıca, Tolerans (.52 - 1.00) ve VIF değerleri (1.00 - 2.32) de kabul edilebilir sınırlar içindedir. Otokorelasyonu test etmede Durbin-Watson katsayısı kullanılmıştır. DurbinWatson değerleri 1.70 ve 1.90 arasında değişmektedir.

\section{Bulgular}

$\mathrm{Bu}$ bölümde, araştırmanın amacına ilişkin bulgulara yer verilmiştir.

OOTÖ Alt Ölçek Puanlarının Demografik Değişkenlere Göre İncelenmesi

Cinsiyet değişkenine göre okul tükenmişliği alt boyutlarına ilişkin t testi sonuçları Tablo 1'de verilmiştir.

Tablo 1

Okul Tükenmişliği Alt Ölçek Puanlarının Cinsiyet Değişkenine Göre İncelenmesi

\begin{tabular}{|c|c|c|c|c|}
\hline OOTÖ Alt Ölçekleri & Cinsiyet & Ort. & Ss & $\mathrm{t}$ \\
\hline \multirow{2}{*}{ Okula Karşı İlgi Kaybı } & $\mathrm{K}$ & 14.86 & 4.85 & \multirow{2}{*}{.81} \\
\hline & $\mathrm{E}$ & 14.58 & 4.57 & \\
\hline \multirow{2}{*}{ Ders Çalışmaktan Tükenme } & K & 15.45 & 3.88 & \multirow{2}{*}{1.10} \\
\hline & $\mathrm{E}$ & 15.78 & 4.06 & \\
\hline \multirow{2}{*}{ Aileden Kaynaklı Tükenme } & K & 11.59 & 4.02 & \multirow{2}{*}{$4.61^{*}$} \\
\hline & $\mathrm{E}$ & 12.94 & 3.70 & \\
\hline \multirow{2}{*}{ Ödev Yapmaktan Tükenme } & K & 13.39 & 3.71 & \multirow{2}{*}{$2.25^{* *}$} \\
\hline & $\mathrm{E}$ & 14.01 & 3.57 & \\
\hline \multirow{2}{*}{$\begin{array}{l}\text { Öğretmen Tutumlarından } \\
\text { Bunalma ve Sıkılma }\end{array}$} & K & 9.55 & 2.96 & \multirow{2}{*}{$2.75^{*}$} \\
\hline & $\mathrm{E}$ & 10.17 & 2.98 & \\
\hline \multirow{2}{*}{ Dinlenme- Eğlenme Gereksinimi } & K & 10.24 & 2.94 & \multirow{2}{*}{.01} \\
\hline & $\mathrm{E}$ & 10.24 & 3.10 & \\
\hline \multirow{2}{*}{ Okulda Yetersizlik } & K & 10.85 & 2.67 & \multirow{2}{*}{$3.73^{*}$} \\
\hline & $\mathrm{E}$ & 10.08 & 2.73 & \\
\hline
\end{tabular}

$* p<.001, * * p<.05 ; \mathrm{N}_{\mathrm{K} 1 \mathrm{z}}=337, \mathrm{~N}_{\mathrm{Erkek}}=364$ 
OOTÖ aileden kaynaklı tükenme, ödev yapmaktan tükenme, öğretmen tutumlarından bunalma, okulda yetersizlik alt ölçek puan ortalamaları cinsiyete göre farklılık göstermektedir. Erkek öğrencilerin aileden kaynaklı tükenme, ödev yapmaktan tükenme ve öğretmen tutumlarından bunalma ve sikılma alt ölçek puan ortalamaları, kız öğrencilerin ise okulda yetersizlik alt ölçek puan ortalamaları daha yüksek bulunmuştur (Tablo 1). Okul türü, algılanan ders başarısı, sınıf düzeyi, anne-baba eğitim düzeyi, devamsızlık süresi ve günlük ders çalışma süresi değişkenlerine göre okul tükenmişliği alt boyutlarına ilişkin Tek Faktörlü Varyans Analizi sonuçları Tablo 2'de verilmiştir. 
Tablo 2

Okul Tükenmişliği Alt Ölçek Puanlarının Diğer Demografik Değişkenlere Göre İncelenmesi

\begin{tabular}{|c|c|c|c|c|c|c|c|c|c|c|c|c|c|c|c|c|c|c|c|c|c|c|c|}
\hline & & \multirow[t]{2}{*}{$\mathrm{N}$} & \multicolumn{3}{|c|}{ Okula Karşı İlgi Kaybı } & \multicolumn{3}{|c|}{$\begin{array}{l}\text { Ders Çalışmaktan } \\
\text { Tükenme }\end{array}$} & \multicolumn{3}{|c|}{$\begin{array}{l}\text { Aileden Kaynaklı } \\
\text { Tükenme }\end{array}$} & \multicolumn{3}{|c|}{$\begin{array}{l}\text { Ödev Yapmaktan } \\
\text { Tükenme }\end{array}$} & \multicolumn{3}{|c|}{$\begin{array}{c}\text { Öğretmen } \\
\text { Tutumlarından } \\
\text { Bunalma }\end{array}$} & \multicolumn{3}{|c|}{$\begin{array}{l}\text { Dinlenme- Ĕglenme } \\
\text { Gereksinimi }\end{array}$} & \multicolumn{3}{|c|}{ Okulda Yetersizlik } \\
\hline & & & Ort. & Ss & $F$ & Ort. & Ss & $F$ & Ort. & Ss & $F$ & Ort. & Ss & $F$ & Ort. & Ss & $F$ & Ort. & Ss & $F$ & Ort. & Ss & $F$ \\
\hline Okul & And. & 261 & 14.80 & 4.90 & \multirow{3}{*}{$9.07^{*}$} & 15.41 & 4.14 & \multirow{3}{*}{$12.31^{*}$} & 12.57 & 3.90 & \multirow{3}{*}{$12.78^{*}$} & 14.16 & 3.67 & \multirow{3}{*}{$15.61^{*}$} & 10.22 & 3.07 & \multirow{3}{*}{$3.53^{* * *}$} & 10.53 & 3.02 & \multirow{3}{*}{$3.85^{5 * * *}$} & 10.45 & 2.84 & \multirow[t]{3}{*}{.82} \\
\hline \multirow[t]{2}{*}{ Türü } & Msl. & 205 & 13.66 & 4.60 & & 14.79 & 3.73 & & 13.08 & 3.48 & & 12.54 & 3.75 & & 9.86 & 3.07 & & 9.77 & 3.01 & & 10.63 & 2.69 & \\
\hline & Fen & 235 & 15.55 & 4.42 & & 16.60 & 3.81 & & 11.30 & 4.09 & & 14.24 & 3.30 & & 9.51 & 2.78 & & 10.34 & 2.99 & & 10.29 & 2.63 & \\
\hline \multirow[t]{4}{*}{ Sinif } & 9 & 195 & 13.52 & 4.59 & \multirow{4}{*}{$9.82^{*}$} & 14.76 & 3.95 & & 12.20 & 3.86 & \multirow{4}{*}{0.46} & 12.06 & 3.73 & & 9.09 & 2.82 & \multirow{4}{*}{$6.43^{*}$} & 9.63 & 2.89 & \multirow{4}{*}{$4.02^{* *}$} & 10.37 & 2.62 & \\
\hline & 10 & 191 & 14.32 & 4.61 & & 15.83 & 4.08 & $5.14^{* *}$ & 12.42 & 4.06 & & 13.82 & 3.53 & $23.56^{*}$ & 10.13 & 3.04 & & 10.63 & 3.05 & & 10.44 & 2.85 & .37 \\
\hline & 11 & 187 & 15.89 & 4.61 & & 15.77 & 3.75 & & 12.09 & 4.15 & & 14.40 & 3.31 & & 10.16 & 2.89 & & 10.39 & 3.00 & & 10.39 & 2.64 & \\
\hline & 12 & 128 & 15.41 & 4.74 & & 16.42 & 3.98 & & 12.55 & 3.41 & & 15.07 & 3.28 & & 10.27 & 3.09 & & 10.38 & 3.08 & & 10.67 & 2.85 & \\
\hline Anne & İlkokul & 276 & 14.39 & 4.64 & & 15.27 & 3.93 & & 12.28 & 3.61 & & 13.39 & 3.75 & & 9.82 & 3.06 & & 10.11 & 3.02 & & 10.73 & 2.71 & \\
\hline eğt. & Ortaokul & 136 & 14.51 & 4.46 & 1.38 & 15.58 & 4.08 & 1.53 & 12.94 & 3.95 & $3.50^{* * *}$ & 13.39 & 3.51 & $3.99^{* *}$ & 10.13 & 2.72 & 1.17 & 10.42 & 3.01 & 1.25 & 10.72 & 2.58 & $3.67^{* * * *}$ \\
\hline & Lise & 147 & 15.20 & 5.08 & & 15.90 & 3.98 & & 12.52 & 4.04 & & 14.60 & 3.68 & & 10.06 & 3.03 & & 10.57 & 3.02 & & 10.14 & 2.67 & \\
\hline & Üniversite & 142 & 14.95 & 4.64 & & 16.07 & 3.93 & & 11.46 & 4.19 & & 13.71 & 3.45 & & 9.54 & 3.03 & & 9.98 & 3.02 & & 9.95 & 2.87 & \\
\hline Baba & İlkokul & 175 & 14.25 & 6.61 & & 15.24 & 4.04 & & 12.42 & 3.67 & & 12.97 & 3.81 & & 9.61 & 3.02 & & 10.02 & 2.94 & & 10.84 & 2.71 & \\
\hline eğt. & Ortaokul & 128 & 14.34 & 4.72 & 1.96 & 14.96 & 3.68 & $3.10^{* * *}$ & 12.75 & 3.83 & $4.14^{* *}$ & 13.21 & 3.44 & $6.12^{*}$ & 9.98 & 2.96 & 2.03 & 10.42 & 3.09 & 1.76 & 10.64 & 2.60 & $3.14^{* * * *}$ \\
\hline & Lise & 154 & 14.69 & 5.02 & & 15.84 & 4.01 & & 12.84 & 3.89 & & 14.46 & 3.48 & & 10.35 & 3.00 & & 10.65 & 3.02 & & 10.48 & 2.84 & \\
\hline & Üniversite & 244 & 15.27 & 4.53 & & 16.11 & 4.00 & & 11.61 & 4.06 & & 14.03 & 3.63 & & 9.71 & 2.88 & & 10.04 & 3.03 & & 10.05 & 2.70 & \\
\hline Devam & $0-5$ gün & 233 & 13.09 & 4.50 & & 14.73 & 3.83 & & 12.17 & 3.90 & & 12.24 & 3.82 & & 9.13 & 3.07 & & 9.87 & 3.12 & & 10.16 & 2.66 & \\
\hline Durumu & 6-10 gün & 190 & 14.72 & 4.61 & $10.21^{*}$ & 15.27 & 3.86 & $6.87^{*}$ & 12.49 & 4.11 & 1.26 & 13.65 & 3.36 & $15.00^{*}$ & 10.05 & 2.92 & $5.19^{*}$ & 10.23 & 3.11 & 1.65 & 10.74 & 2.66 & 1.52 \\
\hline & 11-15 gün & 68 & 15.80 & 4.74 & & 16.51 & 4.04 & & 11.83 & 3.96 & & 14.67 & 3.29 & & 9.95 & 2.87 & & 10.77 & 2.82 & & 10.04 & 3.20 & \\
\hline & 16-20 gün & 79 & 15.81 & 4.37 & & 16.08 & 3.67 & & 11.75 & 3.95 & & 14.49 & 3.18 & & 10.08 & 2.45 & & 10.10 & 2.71 & & 10.50 & 2.59 & \\
\hline & 21-30 gün & 78 & 16.41 & 4.75 & & 17.16 & 4.40 & & 12.48 & 3.51 & & 15.23 & 3.20 & & 10.47 & 2.82 & & 10.66 & 3.10 & & 10.56 & 2.56 & \\
\hline & $\begin{array}{l}30 \text { ve } \\
\text { üzeri }\end{array}$ & 63 & 15.82 & 4.39 & & 16.41 & 3.72 & & 13.17 & 3.69 & & 15.20 & 3.45 & & 10.88 & 3.31 & & 10.65 & 2.81 & & 10.84 & 2.93 & \\
\hline Algilanan & Zayıf & 50 & 16.28 & 4.77 & & 18.04 & 4.19 & & 13.94 & 4.31 & & 14.88 & 3.36 & & 10.98 & 2.88 & & 10.62 & 2.86 & & 11.48 & 2.33 & \\
\hline başarı & Orta & 303 & 15.09 & 4.77 & $6.05^{*}$ & 16.10 & 3.90 & $13.67^{*}$ & 12.63 & 3.78 & $5.93^{* *}$ & 13.87 & 3.57 & $4.08^{* *}$ & 10.10 & 2.90 & $4.51^{* *}$ & 10.16 & 3.03 & .32 & 10.96 & 2.63 & $13.61^{*}$ \\
\hline & İyi & 293 & 13.91 & 4.37 & & 14.69 & 3.61 & & 11.76 & 3.74 & & 13.23 & 3.65 & & 9.53 & 2.97 & & 10.25 & 2.98 & & 10.00 & 2.63 & \\
\hline & Çok İyi & 55 & 15.56 & 5.36 & & 15.76 & 4.69 & & 11.78 & 4.61 & & 14.30 & 4.00 & & 9.47 & 3.93 & & 10.29 & 3.26 & & 9.10 & 3.22 & \\
\hline & Hiç & 298 & 15.21 & 4.91 & & 17.13 & 3.93 & & 12.82 & 3.83 & & 14.38 & 3.48 & & 10.39 & 2.96 & & 10.16 & 3.08 & & 10.72 & 2.68 & \\
\hline çalışma & 1 saat & 96 & 14.27 & 4.55 & 1.95 & 14.87 & 3.50 & $21.53^{*}$ & 12.65 & 3.52 & $5.35^{*}$ & 12.83 & 3.40 & $4.87^{* *}$ & 9.77 & 2.71 & $5.20^{*}$ & 10.08 & 2.80 & .35 & 10.26 & 2.55 & $3.26^{* * * *}$ \\
\hline süresi & 2 saat & 147 & 14.11 & 4.36 & & 14.70 & 3.38 & & 12.27 & 3.94 & & 13.26 & 3.55 & & 9.76 & 3.06 & & 10.42 & 2.99 & & 10.70 & 2.66 & \\
\hline & 3 saat & 108 & 14.35 & 4.92 & & 14.12 & 3.81 & & 11.19 & 3.90 & & 13.99 & 4.03 & & 9.08 & 2.76 & & 10.22 & 3.14 & & 9.87 & 2.85 & \\
\hline & $\begin{array}{l}4 \text { saat ve } \\
\text { üzeri }\end{array}$ & 52 & 15.17 & 4.79 & & 14.11 & 4.17 & & 10.96 & 4.36 & & 14.42 & 3.98 & & .09 & 3.36 & & 10.51 & 2.97 & & 9.75 & 3.00 & \\
\hline
\end{tabular}

$* p<.001, * * p<.01, * * * p<.05$. 
Analiz sonucunda OOTÖ alt ölçek puanlarının bazı değişkenlere göre farklılık gösterdiği bulunmuştur (Tablo 2). Farklılıkların hangi gruplardan kaynaklandığını belirleyebilmek için Tukey testi yapılmıştır. Okul tükenmişliği okula karşı ilgi kaybı alt ölçek puanları; okul türü, sınıf düzeyi, devamsızlık ve algılanan başarı değişkenlerine göre farklılık göstermektedir. Fen lisesi öğrencilerinin, 21-30 gün devamsızlığ olan ve algılanan başarı düzeyi zayıf olan öğrencilerin puan ortalamalarının diğerlerine göre daha yüksek, 9. Sınıf öğrencilerinin puan ortalamalarının ise diğerlerine göre daha düşük olduğu görülmüştür. $O k u l$ tükenmişliği ders çalışmaktan tükenme alt ölçek puanları; okul türü, sınıf düzeyi, baba eğitim durumu, devamsızlık, algılanan başarı ve ders çalışma süresine göre farklılık göstermektedir. Fen lisesi öğrencilerinin, baba eğitim durumunu üniversite olarak belirten, 21-30 gün devamsızlığı olan, ders çalışmadığını belirten ve algılanan başarı düzeyi zayıf olan öğrencilerin puan ortalamalarının diğerlerine göre daha yüksek, 9. Sınıf öğrencilerinin diğerlerine göre daha düşük olduğu bulunmuştur. Okul tükenmişliği aileden kaynaklı tükenme alt ölçek puanları; okul türü, anne eğitim durumu, baba eğitim durumu, algılanan başarı, ders çalışma süresi ve cinsiyet değişkenlerine göre farklılık göstermektedir. Meslek lisesi öğrencilerinin, anne eğitim durumunu ortaokul, baba eğitim durumunu lise olarak belirtilen öğrencilerin, algılanan başarı düzeyi zayıf olan ve ders çalışmadığını belirten öğrencilerin puan ortalamalarının diğerlerine göre daha yüksek olduğu gözlenmiştir. Öğrencilerin okul tükenmişliği ödev yapmaktan tükenme alt ölçek puanları; okul türü, sınıf düzeyi, anne eğitim durumu, baba eğitim durumu, devamsızlık durumu, algılanan başarı ve ders çalışma süresi değişkenlerine göre farklılık göstermektedir. Meslek lisesi öğrencilerinin, 9 sınıf öğrencilerinin ve devamsızlığ $0-5$ gün olan öğrencilerin puan ortalamalarının diğerlerine göre daha düşük görülmektedir. Anne ve baba eğitim durumunu lise olarak belirten öğrencilerin, algılanan başarı düzeyi zayıf olan öğrencilerin, ders çalışmadığını ve 4 saat üzeri ders çalıştığını belirten öğrencilerin puan ortalamalarının diğerlerine göre daha yüksek olduğu gözlenmiştir. Okul tükenmişliği ögretmen tutumlarından bunalma ve sıkılma alt ölçek puanları; okul türü, sınıf düzeyi, devamsızlık, algılanan başarı, ders çalışma süresi değişkenlerine göre farklılık göstermektedir. Anadolu Lisesi öğrencilerinin, devamsızlığı 30 gün ve üzerinde olan, algılanan başarı düzeyi zayıf olan öğrencilerin, ders çalışmadığını belirten öğrencilerin puan ortalamalarının diğerlerine göre daha yüksek olduğu, 9 sınıf öğrencilerinin puan ortalamalarının ise diğerlerine göre daha düşük olduğu bulunmuştur. Okul tükenmişliği dinlenme-eğlenme gereksinimi alt ölçek puanları; okul türü ve sınıf düzeyi değişkenlerine göre farkl1lık göstermektedir. Meslek lisesi öğrencilerinin ve 9. Sınıf öğrencilerinin puan ortalamalarının diğerlerine göre daha düşük olduğu görülmüştür. Ölçeğin okulda yetersizlik alt ölçek puanları; algılanan başarı, anne eğitim durumu, baba eğitim durumu ve ders çalışma süresi değişkenlerine göre farklılık göstermektedir. Başarı durumunu zayıf ve orta olarak algılayan, ders çalışmadığını belirten öğrencilerin puan ortalamalarının diğerlerinden daha yüksek olduğu, anne ve baba eğitim durumunu üniversite olarak belirtilen öğrencilerin puan ortalamalarının diğerlerine göre daha düşük olduğu bulunmuştur (Tablo 2).

Değişkenler Arasındaki İiş̧kiler

Değişkenler arasındaki ilişkileri incelemek için Pearson Momentler Çarpımı Korelasyon analizi kullanılmış ve sonuçlar Tablo 3'de sunulmuştur.

Tablo 3

Değişkenler Arasındaki Korelasyon Katsayıları ile Değişkenlere İlişkin Aritmetik Ortalama ve Standart Sapma Değerleri

\begin{tabular}{lcccccccccc}
\hline Değişkenler & Ort. & Ss & İK & DK & OKİK & DÇT & AKT & ÖYT & ÖTB & DEG \\
\hline İK & 23.69 & 4.86 & - & & & & & & & \\
DK & 28.01 & 6.78 & $-.20^{*}$ & - & & & & & & \\
OOTÖ & & & & & & & & & & \\
$\quad$ OKIK & 14.72 & 4.71 & $-.21^{*}$ & $.16^{*}$ & - & & & & & \\
DÇT & 15.62 & 3.98 & $-.21^{*}$ & $.21^{*}$ & $.53^{*}$ & - & & & & \\
AKT & 12.29 & 3.91 & $-.17^{*}$ & $.28^{*}$ & $.11^{*}$ & $.23^{*}$ & - & & &
\end{tabular}




\begin{tabular}{lcccccccccc} 
ÖYT & 13.71 & 3.65 & $-.19^{*}$ & $.19^{*}$ & $.42^{*}$ & $.50^{*}$ & $.25^{*}$ & - & & \\
ÖTBS & 9.87 & 2.99 & $-.28^{*}$ & $.29^{*}$ & $.32^{*}$ & $.37^{*}$ & $.49^{*}$ & $.48^{*}$ & - & \\
DEG & 10.24 & 3.02 & $-.16^{*}$ & $.12^{*}$ & $.28^{*}$ & $.24^{*}$ & $.33^{*}$ & $.43^{*}$ & $.46^{*}$ & - \\
OY & 10.45 & 2.73 & -.02 & $.13^{*}$ & $.19^{*}$ & $.15^{*}$ & $.28^{*}$ & $.14^{*}$ & $.23^{*}$ & $.19^{*}$ \\
\hline
\end{tabular}

" $p<.01$; İçsel Kontrol İK; Dışsal Kontrol DK; Okula Karşı İlgi Kaybı OKİK; Ders Çalışmaktan Tükenme DÇT; Aileden Kaynaklı Tükenme AKT; Ödev Yapmaktan Tükenme ÖYT; Öğretmen Tutumlarından Bunalma ve Sıkılma ÖTBS; Dinlenme- Eğlenme Gereksinimi DEG; Okulda Yetersizlik OY.

Ergenlerin içsel kontrol puanları ile OOTÖ okula karşı ilgi kaybı $(r=-.21, p<.01)$, ders çalışmaktan tükenme $(r=-.21, p<.01)$, aileden kaynaklı tükenme $(r=-.17, p<.01)$, ödev yapmaktan tükenme $(r=-.19, p<.01)$, öğretmen tutumlarından bunalma ve sıkılma $(r=-.28$, $p<.01)$ ile dinlenme- eğlenme gereksinimi $(r=-.16, p<.01)$ alt ölçek puanları arasında negatif yönde bir ilişkinin olduğu görülmektedir (Tablo 3). Okulda Yetersizlik alt ölçek puanları ile içsel kontrol puanları arasında ise anlamlı bir ilişki bulunmamıştır $(r=-.02, p>.05)$. Ergenlerin dışsal kontrol puanları ile OOTÖ okula karşı ilgi kaybı $(r=.16, p<.01)$, ders çalışmaktan tükenme $(r=.21, p<.01)$, aileden kaynaklı tükenme $(r=.28, p<.01)$, ödev yapmaktan tükenme $(r=.19, p<.01)$, ögretmen tutumlarından bunalma ve sıkılma $(r=.29, p<.01)$, dinlenme- eğlenme gereksinimi $(r=.12, p<.01)$ ve okulda yetersizlik $(r=.13, p<.01)$ alt ölçek puanları arasında pozitif yönde bir ilişkinin olduğu görülmektedir (Tablo 3).

OOTÖ Alt Ölçek puanlarında farklılık oluşturan demografik değişkenler "dummy" değişken olarak yeniden tanımlanmış ve hiyerarşik regresyon analizinde ilk blokta analize dahil edilmiştir. Demografik değişkenler $t$ testi ve Anova sonuçlarına göre analize dahil edilmiştir, bu nedenle her alt ölçek için ilk blokta girilen demografik değişkenler ve sıralaması faklıdır.

Tablo 4

Çoklu Hiyerarşik Regresyon Analizi Sonuçları

\begin{tabular}{|c|c|c|c|c|c|c|c|c|}
\hline Yordanan & Model & Yordayıc1 & $\beta$ & $t$ & $R$ & $R^{2}$ & $R_{c h}^{2}$ & $F_{c h}$ \\
\hline \multirow{6}{*}{ OKİK } & 1 & Devamsızlık durumu & .19 & $4.02^{*}$ & \multirow{4}{*}{.28} & \multirow{4}{*}{.08} & \multirow{4}{*}{.08} & \multirow{4}{*}{$14.73^{*}$} \\
\hline & & Sınıf düzeyi & .11 & $2.22^{* * *}$ & & & & \\
\hline & & Okul türü & .10 & $2.74^{* *}$ & & & & \\
\hline & & Alg. başarı & -.11 & $-2.99^{* *}$ & & & & \\
\hline & \multirow[t]{2}{*}{2} & $\dot{\mathrm{I} K}$ & -.17 & $-4.61^{*}$ & \multirow{2}{*}{.35} & \multirow{2}{*}{.12} & \multirow{2}{*}{.04} & \multirow{2}{*}{$16.26^{*}$} \\
\hline & & DK & .09 & $2.40^{* * *}$ & & & & \\
\hline \multirow{8}{*}{ DÇT } & 1 & Ders çal. süresi & -.17 & $-7.50^{*}$ & \multirow{6}{*}{.41} & \multirow{6}{*}{.17} & \multirow{6}{*}{.17} & \multirow{6}{*}{$23.51 *$} \\
\hline & & Okul türü & .10 & $2.82^{* *}$ & & & & \\
\hline & & Alg. başarı & -.13 & $-3.46^{* *}$ & & & & \\
\hline & & Devamsızlık durumu & .15 & $3.36^{* *}$ & & & & \\
\hline & & Sınıf düzeyi & .10 & $2.20^{* * *}$ & & & & \\
\hline & \multirow{3}{*}{2} & Baba eğt. durumu & .09 & $2.38^{* * *}$ & & & & \\
\hline & & İK & -.14 & $-4.11^{*}$ & \multirow{2}{*}{.45} & \multirow{2}{*}{.21} & \multirow{2}{*}{.04} & \multirow{2}{*}{$15.79^{*}$} \\
\hline & & DK & .11 & $2.99^{* *}$ & & & & \\
\hline \multirow{8}{*}{ AKT } & 1 & Okul türü & -.14 & $-3.62^{*}$ & \multirow{6}{*}{.30} & \multirow{6}{*}{.09} & \multirow{6}{*}{.09} & \multirow{6}{*}{$11.52^{*}$} \\
\hline & & Ders çal. süresi & -.12 & $-3.21^{* *}$ & & & & \\
\hline & & Cinsiyet & .16 & $4.44^{*}$ & & & & \\
\hline & & Alg. Başarı & -.13 & $-3.47^{* *}$ & & & & \\
\hline & & Baba eğt. Durumu & -.08 & -1.66 & & & & \\
\hline & & Anne eğt. durumu & .03 & .66 & & & & \\
\hline & \multirow[t]{2}{*}{2} & İK & -.10 & $-2.64^{* *}$ & \multirow{2}{*}{.39} & \multirow{2}{*}{.15} & \multirow{2}{*}{.06} & \multirow{2}{*}{$25.07^{*}$} \\
\hline & & DK & .22 & $5.98^{*}$ & & & & \\
\hline & 1 & Sınıf düzeyi & .23 & $5.02^{*}$ & & & & \\
\hline & & Okul türü & .03 & .69 & & & & \\
\hline & & Devamsızlık durumu & .15 & $3.30^{* *}$ & & & & \\
\hline ÖYT & & Baba eğt. Durumu & .14 & $2.83^{* *}$ & .38 & .15 & .15 & $14.99^{*}$ \\
\hline & & Ders çal. Süresi & -.11 & $-2.85^{* *}$ & & & & \\
\hline & & Alg. Başarı & -.08 & $-2.16^{* * *}$ & & & & \\
\hline & & Anne eğt. Durumu & -.01 & -.16 & & & & \\
\hline
\end{tabular}




\begin{tabular}{|c|c|c|c|c|c|c|c|c|}
\hline & 2 & $\begin{array}{l}\text { Cinsiyet } \\
\text { İK } \\
\text { DK }\end{array}$ & $\begin{array}{l}.05 \\
-.14 \\
.11\end{array}$ & $\begin{array}{l}1.43 \\
-3.80^{*} \\
3.04^{* *}\end{array}$ & .42 & .18 & .03 & $13.59^{*}$ \\
\hline \multirow{8}{*}{ ÖTBS } & 1 & Sinıf düzeyi & .06 & 1.21 & \multirow{6}{*}{.29} & \multirow{6}{*}{.09} & \multirow{6}{*}{.09} & \multirow{6}{*}{$10.79^{*}$} \\
\hline & & Ders çal. süresi & -.15 & $-3.98^{*}$ & & & & \\
\hline & & Devamsızlık durumu & .13 & $2.88^{* *}$ & & & & \\
\hline & & Cinsiyet & .08 & $2.20^{* * *}$ & & & & \\
\hline & & Alg. Başarı & -.11 & $-2.85^{* *}$ & & & & \\
\hline & \multirow{3}{*}{2} & Okul türü & -.10 & $-2.52^{* * * *}$ & & & & \\
\hline & & İK & -.21 & $-6.01^{*}$ & \multirow{2}{*}{.42} & \multirow{2}{*}{.18} & \multirow{2}{*}{.09} & \multirow{2}{*}{$39.12^{*}$} \\
\hline & & DK & .20 & $5.64^{*}$ & & & & \\
\hline \multirow{3}{*}{ DEG } & 1 & Sinıf düzeyi & .08 & $2.01^{* * *}$ & \multirow[t]{2}{*}{.08} & \multirow[t]{2}{*}{.01} & \multirow[t]{2}{*}{.01} & \multirow[t]{2}{*}{2.33} \\
\hline & \multirow{2}{*}{2} & $\begin{array}{l}\text { Okul türü } \\
\text { İK }\end{array}$ & $\begin{array}{l}-.01 \\
-.14\end{array}$ & $\begin{array}{l}-.33 \\
-3.68^{*}\end{array}$ & & & & \\
\hline & & DK & & $2.40^{* * * *}$ & .20 & .04 & .03 & $11.98^{*}$ \\
\hline \multirow{7}{*}{ OY } & 1 & Alg. Başarı & -.21 & $-5.95^{*}$ & \multirow{5}{*}{.29} & \multirow{5}{*}{.09} & \multirow{5}{*}{.09} & \multirow{5}{*}{$13.60^{*}$} \\
\hline & & Cinsiyet & -.13 & $-3.52^{*}$ & & & & \\
\hline & & Anne eğt. Durumu & -.07 & -1.35 & & & & \\
\hline & & Ders çal. Süresi & -.04 & -1.02 & & & & \\
\hline & \multirow{3}{*}{2} & Baba eğt. Durumu & -.07 & -1.39 & & & & \\
\hline & & İK & .02 & .15 & \multirow{2}{*}{.32} & \multirow{2}{*}{.10} & \multirow{2}{*}{.01} & \multirow{2}{*}{$5.59^{* *}$} \\
\hline & & DK & .13 & $3.31^{* *}$ & & & & \\
\hline
\end{tabular}

"p< .01; İçsel Kontrol İK; Dışsal Kontrol DK; Okula Karşı İlgi Kaybı OKİK; Ders Çalışmaktan Tükenme DÇT; Aileden Kaynaklı Tükenme AKT; Ödev Yapmaktan Tükenme ÖYT; Öğretmen Tutumlarından Bunalma ve Sıkılma ÖTB; Dinlenme- Eğlenme Gereksinimi DEG; Okulda Yetersizlik OY.

Akademik kontrol içsel ve dışsal kontrol boyutları demografik değişkenlerle birlikte okul tükenmişliğinin okula karşı ilgi kaybı alt boyutunun \%12'sini, ders çalışmaktan tükenme alt boyutunun \%21'ini, aileden kaynakl1 tükenme alt boyutunun \%15'ini, ödev yapmaktan tükenme alt boyutunun \%18'ini, öğretmen kaynakl1 tükenme alt boyunun \%18'ini ve okulda yetersizlik alt boyutunun \%10'unu açıkladığı görülmektedir. Ayrıca okul tükenmişliğini içsel kontrol odağının negatif, dışsal kontrol odağının ise pozitif olarak yordadığı bulunmuştur (Tablo 4).

\section{Tartışma, Sonuç ve Öneriler}

$\mathrm{Bu}$ çalışmada, ergenlerde okul tükenmişliği ile akademik kontrol odağı arasındaki ilişki incelenmiştir. Bu çalışmada bulgular üç aşamada ele alınmıştır. İlk aşamada OOTÖ alt ölçek puanları demografik değişkenlere (okul türü, cinsiyet, sınıf düzeyi, anne-baba eğitim düzeyi, okul devamsızlığı, algılanan akademik başarı ve günlük düzenli ders çalışma saati) göre incelenmiştir. Bulgular bu değişkenlere göre okul tükenmişliğinin bir ya da birden fazla alt boyutundan elde edilen puanlarda anlamlı farklılıklar olduğunu göstermiştir. Bu bulgulardan biri okul türüne göre farklılıklardır. Fen lisesi öğrencilerinin okula karşı ilgi kaybı, ders çalışmaktan tükenme ve ödev yapmaktan tükenme alt ölçek puanları diğerlerine göre daha yüksek bulunurken, meslek lisesi öğrencilerinin aileden kaynaklı tükenme alt ölçek puanları diğgerlerine göre daha yüksektir. Anadolu Lisesi öğrencilerinin öğretmen tutumlarından bunalma ve sıkılma ile dinlenme-eğlenme gereksinimi alt ölçek puanları diğerlerine göre daha yüksektir. $\mathrm{Bu}$ durum Anadolu ve fen liselerinde diğer liselere göre müfredatın daha yoğun olması ve aileöğretmen gibi öğrencilerin çevresindeki kişilerin öğrencilerden beklentilerinin yüksek olması ile ilişkili olabileceğini düşündürmektedir. Seçer ve Gençdoğan (2012) çalışmalarında okula ilgi kaybı alt boyutunda ve ders çalışmaktan tükenme boyutlarında düz lise öğrencilerinin diğer liselerde öğrenim gören öğrencilere kıyasla daha yüksek düzeyde tükenmişlik yaşadıklarını; aileden kaynaklanan tükenmişlik boyutunda ise Anadolu liselerinde öğrenim gören öğrencilerin tükenmişlik düzeylerinin sosyal bilimler ve öğretmen liselerinde öğrenim gören öğrencilere göre daha yüksek olduğunu bulmuşlardır. 
Cinsiyet farklılıkları incelendiğinde, erkek öğrencilerin aileden kaynaklı tükenme, ödev yapmaktan tükenme ve ögretmen tutumlarından bunalma ve sıkılma alt ölçek puan ortalamaları, kız öğrencilerin ise okulda yetersizlik alt ölçek puan ortalamaları daha yüksek olduğu görülmektedir. Bu bulgu lise öğrencilerinde erkeklerin kızlardan daha fazla tükenmişlik yaşadığını gösteren araştırma bulgularıyla paralellik göstermektedir (Acar ve Çakır, 2015; Aypay ve Sever, 2015; Çapulcuoğlu ve Gündüz, 2013; Öztan, 2014; Salmela-Aro ve diğerleri, 2008; Salmela-Aro ve Tynkkynen, 2012; Seçer ve Gençdoğan, 2012; Sever ve Aypay, 2011). Acar ve Çakır (2015) ile Sever ve Aypay'ın (2011) çalışmalarında, ders çalışmaktan tükenme ve ödev yapmaktan tükenme alt boyutlarında erkek öğrencilerin; okulda yetersizlik alt boyutunda kızların daha fazla tükenmişlik yaşadıkları bulunmuştur. Seçer ve Gençdoğan'ın (2012) bulguları erkek öğrencilerin okula ilgi kaybı, ödev yapmaktan tükenme, öğretmen tutumlarından bunalma ve dinlenme-eğlenme gereksinimi alt boyutlarında daha fazla tükenmişlik yaşadıkları yönündedir. Diğer taraftan cinsiyet açısından farklılık bulmayan araştırma sonuçlarıyla (Çapri ve Yedigöz-Sönmez, 2013; Gündüz, 2004; Kutsal ve Bilge, 2012; Tümkaya ve Çavuşoğlu, 2010) bu çalışmanın bulguları örtüşmemektedir. Erkeklerin tükenmişlik düzeylerinin kızlara göre birçok boyutta yüksek olması cinsiyet rolleri ile açılanabilir. Sosyalleşme sürecinde aile ve toplum tarafından beklenen davranışların ve kişilik özelliklerinin sergilenmesi erkekler üzerinde daha fazla baskı oluşturuyor (Çapulcuoğlu ve Gündüz, 2013) böylece de özellikle okul, eğitim ve akademik başarı gibi konularda oluşan bu baskı okul tükenmişliğini artırıyor olabilir. $\mathrm{Bu}$ çalışmada literatürle paralel olarak sınıf düzeyine göre en az tükenmişlik yaşayanların 9. sınıf öğrencileri olduğu saptanmıştır (Aypay ve Sever, 2015; Kutsal, 2009; Kutsal ve Bilge, 2012; Sever ve Aypay, 2011). Kutsal (2009) çalışmasında, sınıf düzeyi yükseldikçe, tükenme düzeyinin de arttığı sonucuna ulaşmıştır. Çapulcuoğlu ve Gündüz (2013) ise 9. sınıf öğrencilerinin en yüksek tükenmişlik düzeyine sahip olduğunu bulmuşlardır. Diğer bulgulardan biri okul devamsızlığı ile ilgilidir. Okul devamsızlığı 21-30 gün olan öğrencilerin okula karşı ilgi kaybı, ders çalışmaktan ve ödev yapmaktan dolayı tükenme yaşadıkları, devamsızlığ 30 gün ve daha fazla olan öğrencilerin öğretmen tutumlarından bunaldıkları belirlenmiştir. Anneleri ortaokul mezunu olan öğrencilerin aileden kaynaklı tükenme, anneleri ve babaları lise mezunu olan öğrencilerin ödev yapmaktan tükenme, babaları üniversite mezunu olan öğrencilerin ders çalışmaktan tükenme yaşamakta, anneleri ve babaları üniversite mezunu olan öğrenciler ise okulda daha az yetersizlik yaşamaktadırlar.

$\mathrm{Bu}$ çalışmanın bulgularından bir diğeri, akademik başarısını zayıf olarak algılayan öğrencilerin okula karşı ilgi kaybı, ders çalışmaktan tükenme, aileden kaynaklı tükenme, ödev yapmaktan tükenme, öğretmen tutumlarından bunalma ve sıkılma ile okulda yetersizlik alt ölçek puanlarının diğerlerine göre daha yüksek olduğudur. Bu bulgu akademik başarı ve okul tükenmişliği arasında anlamlı bir ilişki olduğunu (Çapulcuoğlu ve Gündüz, 2013; Kutsal ve Bilge, 2012; Sever ve Aypay, 2011; Salmela-Aro ve diğerleri, 2008) gösteren araştırma bulgularıyla örtüşmektedir. Kutsal ve Bilge (2012), orta ve yükssek başarı algısını karşılaştırdığ çalışmasında kendini orta düzeyde başarılı algılayan öğrencilerin tükenmişlik düzeylerinin daha yüksek olduğunu saptamışlardır. Akademik başarısını zayıf olarak algılayan öğrenciler, yakın çevrelerinin kendilerinden başarı beklentileri nedeniyle okul tükenmişliği yaşıyor olabilirler. Aynı zamanda ders çalışmadığını belirten öğrencilerin ders çalışmaktan tükenme, aileden kaynaklı tükenme, öğretmen tutumlarından bunalma ve sıkılma ile okulda yetersizlik, 4 saat ve daha fazla ders çalıştığını belirten öğrencilerin ise ödev yapmaktan tükenme alt ölçek puanları diğerlerine göre daha yüksek olduğu bulunmuştur.

Çalışmanın ikinci aşamasında değişkenler arasındaki ilişkiler incelenmiş ve okul tükenmişliği alt boyutları ile içsel kontrol odağı arasında orta düzeyde ve negatif yönde, okul tükenmişliği alt boyutları ile dışsal kontrol odağı arasında orta düzeyde ve pozitif yönde bir ilişkinin olduğu görülmüş̧ür. Son aşamada ise, akademik kontrol içsel ve dişsal kontrol boyutları OOTÖ Alt Ölçek puanlarında farklılık oluşturan demografik değişkenlerle birlikte okul tükenmişliğinin okula karşı ilgi kaybı alt boyutunun \%12'sini, ders çalışmaktan tükenme alt boyutunun \%21'ini, aileden kaynakl1 tükenme alt boyutunun \%15'ini, ödev yapmaktan tükenme alt boyutunun \%18'ini, ögretmen tutumlarından bunalma ve sikılma alt boyunun 
\%18'ini ve okulda yetersizlik alt boyutunun \%10'unu açıkladığı belirlenmiştir. Okul tükenmişliğini içsel kontrol odağı negatif, dışsal kontrol odağ 1 ise pozitif olarak yordamaktadır. Kuramsal açıdan bakıldığında iç kontrol odaklılar, yaşamları üzerindeki kontrolün kendi ellerinde olduğuna inanırlar. Bu bireyler; kazandıkları paraların, yaptıkları işlerin ya da fiziksel sağlıklarının kendi kontrol alanlarında yer aldığına, yaşamlarının herhangi bir alanında mutsuz olduklarında bunu kendi çabalarıyla değiştirebileceklerine inanırlar. Dış kontrol odaklı bireylerin ise stresle mücadele etmenin kendi güç ve yeterliliklerini çok ötesinde olduğuna inanacakları ve bu nedenle aktif bir çözüm arayışı yerine pasif bir biçimde stresin etkilerine katlanmayı tercih edecekleri beklenmektedir (Yeşilyaprak, 2004). Dolayısıyla tükenmişlik dış kontrol odaklı bireylerde iç kontrol odaklı bireylere oranla daha yüksektir. Literatürdeki önceki araştırmalar dıştan denetimliliğin tükenmişlik yaşanmasına yönelik daha fazla risk oluşturan bir kişilik özelliği olduğunu göstermektedir (Bühler ve Land, 2004; Özdemir, 2009; Sarıkaya, 2007; Schmitz, Neumann ve Oppermann, 2000; Sürgen, 2014; Sürgevil, 2006; Wilski, Chmielewski ve Tomczak, 2015).

$\mathrm{Bu}$ çalışmanın sonuçlarına göre, dokuzuncu sınıf öğrencilerinin en az tükenmişlik yaşadığı ve sınıf düzeyi yükseldikçe, tükenme düzeyinin de arttığı dikkate alındığında okul psikolojik danışmanlarının özellikle ilk sınıftan itibaren tükenmişliği önlemeye yönelik planlı olarak bireysel ve grup çalışmaları gerçekleştirmelerinin yararlı olacağı düşünülmektedir. Okul tükenmişliğinin hemen hemen tüm boyutlarında devamsızlık sayısı az olan öğrencilerin tükenmişlik puanlarının düşük olduğu görülmektedir. Okul devamsızlığının birçok nedeni (bireysel nedenler, sağlık sorunları, okul ikliminden, öğretmenlerden, aileden, akademik kaygıdan kaynaklanan nedenler gibi) olabilir. Öncelikle bu nedenler belirlenerek okul devamsızlığını önlemek için çalışmalar yapılabilir. Günlük düzenli ders çalışan öğrencilerin, düzenli ders çalışmayan öğrencilere göre daha az tükenmişlik yaşadıkları görülmektedir. Öğrencilerin düzenli ders çalışma alışkanlığı kazanmaları için grup rehberliği çalışmaları yapılabilir ve ailelere yönelik konsültasyon çalışmaları yapılabilir. Araştırma bulguları ders başarısı iyi olan öğrencilerin tükenmişlik puanlarının düşük olduğunu ortaya koymaktadır. Akademik başarı ve tükenmişlik birbirlerini karşılıklı olarak etkileyen bir süreçtir. Okul psikolojik danışmanı ve öğretmenlerin iş birliği ile öğrencilerin başarı algısını artırmaya yönelik tedbirler alınmalı ve öğrencilerin takibi yapılmalıdır.

Araştırma sonucunda elde edilen bulgularda; içsel kontrolün artması ile okul tükenmişliğinin azaldığı, dışsal kontrolün artmasıyla da okul tükenmişliğinin arttığı sonucu tüm alt boyutlarda göze çarpmaktadır. Kontrol odağı kişiliğin boyutlarından biridir. Uygun şartlar ve eğitim imkânları ile birey dış denetimlilikten iç denetimliliğe geçebilir (Odacı, Kalkan, Balcı ve Yılmaz, 2003; Sardoğan, Kaygusuz ve Karahan, 2006; Spence, 1994). Yeşilyaprak (1990), denetim odağını değiştirmeye dönük araştırmaların beceri eğitimi vermeye, kişisel sorumluluk duygusunu geliştirmeye ve davranış ile sonuç arasındaki ilişkiyi göstermeye yönelik olduğunu belirtmektedir. Örneğin, sosyal beceri eğitiminin bireylerin kişiler arası sorun çözme becerilerini geliştirdiği ve bu sayede yaşamları üzerinde daha fazla kontrol sahibi olduğu bir çalışmayla ortaya konulmuștur (Spence, 1994). Bu nedenle, okul psikolojik danıșma hizmetleri çerçevesinde öğrenci tükenmişliğine ilişkin koruyucu ve önleyici çalışmalar planlanırken özellikle iç kontrol odağ geliştirmeye yönelik psiko-eğitsel çalışmalar yapılabilir ve bunların etkililiği sınanabilir. Bu araştırmanın sınırlı yanı çalışma grubunun İç Anadolu bölgesinde yer alan bir il merkezindeki Anadolu, Meslek ve Fen Liselerine devam eden ergenlerden oluşmasıdır. Gelecekteki çalışmalarda farklı bölgelerden ve farklı lise türünden hatta ilkokul, ortaokul ve yükseköğretimdeki öğrencilerden oluşan çalışma grupları ile araştırmalar yapılabilir. Ayrıca, veriler ergenlerin öz-değerlendirmelerine dayalı olarak elde edilmiştir. Ergenlerin ölçekteki maddelere işaretleme yoluyla verdiği tepkiler gerçek yaşam davranışı ile benzerlik göstermeyebilir. Dolayısıyla sonuçlar ölçme araçlarının sınırları dâhilinde yorumlanmalıdır. 


\section{Kaynaklar}

Acar, H. ve Çakır, M. A. (2015). Lise öğrencilerinin tükenmişlik düzeylerinin incelenmesi: Yeşilova ilçesi örneği. Mehmet Akif Ersoy Üniversitesi Eğitim Fakültesi Dergisi, 34, 152-168.

Akın, A. (2007). Akademik kontrol odağı ölçeği: Geçerlik ve güvenirlik çalışması. Çukurova Üniversitesi Eğitim Fakültesi Dergisi, 34(3), 9-17.

Aypay, A. (2011). Ortaöğretim öğrencileri için okul tükenmişliği ölçeği (OOTÖ). Kuram ve Uygulamada Ĕ̈itim Bilimleri, 12,782-787.

Aypay, A. ve Eryılmaz, A. (2011). Lise öğrencilerinin derse katılmaya motive olmaları ile okul tükenmişliği arasındaki ilişkinin incelenmesi. Mehmet Akif Ersoy Üniversitesi Eğitim Fakültesi Dergisi, 21, 26-44.

Aypay, A. ve Sever, M. (2015). School as if a workplace: Exploring burnout among high school students. Journal of Theory and Practice in Education, 11(2), 460-472.

Balc1, A. (2006). Sosyal bilimlerde araştırma yöntem, teknik ve ilkeler. 6. Baskı, Ankara: Pegem A Yayincilik.

Bühler, K. E. ve Land, T. (2004). Burnout and personality in extreme nursing: An empirical study. Schweizer Archiv für Neurologie und Psychiatrie, 155(1), 35- 42.

Çam, Z., Deniz, K. Z. ve Kurnaz, A. (2014). Okul tükenmişliği: Algılanan sosyal destek, mükemmeliyetçilik ve stres değişkenlerine dayalı bir yapısal eşitlik modelleme sinamas1. Ë̆itim ve Bilim Dergisi, 39(173), 312-327.

Çapri, B., Ozkendir, O. M., Ozkurt, B. ve Karakus, F. (2012). Investigation of pre-service teachers' attitudes towards physics lesson and self-efficacy beliefs according to their gender, departments and perceived success in physics. Procedia-Social and Behavioral Sciences, 47, 1034-1039.

Çapri, B. ve Yedigöz-Sönmez, G. (2013). Lise öğrencilerinin tükenmişlik puanlarının sosyodemografik değişkenler, psikolojik belirtiler ve bağlanma stilleri açısından incelenmesi. International Journal of Human Sciences, 10(2), 195-218.

Çapulcuoğlu, U. ve Gündüz, B. (2013). Lise öğrencilerinde tükenmişliğin cinsiyet, sınıf düzeyi, okul türü ve algılanan akademik başarı değişkenlerine göre incelenmesi. Trakya Üniversitesi Eğitim Fakültesi Dergisi, 3(1), 12-24.

Christensen, L. B., Johnson, B. ve Turner, L. A. (2014). Research methods, design, and analysis. Twelfth Edition, Edinburgh: Pearson Education Limited.

Duru, E., Duru, S. ve Balkıs, M. (2014). Tükenmişlik, akademik başarı ve öz düzenleme arasındaki ilişkilerin analizi. Kuram ve Uygulamada Eğitim Bilimleri, 14(4), 12631284.

Gan, Y., Shang, J. ve Zhang, Y. (2007). Coping flexibility and locus of control as predictors of burnout among Chinese college students. Social Behavior and Personality, 35(8), 1087-1098.

Gündüz, B. (2004). Öğretmenlerde tükenmişliğin akılcı olmayan inançlar ve mesleki bazı değişkenlere göre yordanması (Yayımlanmamış doktora tezi). Çukurova Üniversitesi Sosyal Bilimler Enstitüsü, Adana.

Jacobs, S. R. ve Dodd, D. (2003). Student burnout as a function of personality, social support, and workload. Journal of College Student Development, 44(3), 291-303.

Karaatl1, M. (2006). Verilerin düzenlenmesi ve gösterimi. Ş. Kalaycioğlu (Yay. haz.), SPSS uygulamalı çok değişkenli istatistik teknikleri içinde (s. 3-47). İkinci Baskı, Ankara: Asil Yayın Dağıtım.

Kiuru, N., Aunolo, K., Nurmi, J. E., Leskinen, E. ve Salmelo-Aro, K. (2008). Peer group influence and selection in adolescent's school burnout. Merrill-Palmer Quarterly, 54(1), 23-55.

Kutsal, D. (2009). Lise ögrencilerinin tükenmişliklerinin incelenmesi (Yayımlanmamış yüksek lisans tezi). Hacettepe Üniversitesi, Sosyal Bilimler Enstitüsü, Ankara.

Kutsal, D. ve Bilge, F. (2012). Lise öğrencilerinin tükenmişlik ve sosyal destek düzeyleri. Eğitim ve Bilim, 37(164), 283-297. 
Lou, Y., Wang, Z., Zhang, H., Chen, A. ve Quan, S. (2016). The effect of perfectionism on school burnout among adolescence: The mediator of self-esteem and coping style. Personality and Individual Differences, 88, 202-208.

Maslach, C. ve Jackson, S. E. (1981). The measurement of experienced burnout. Journal of Occupational Behaviour, 2, 99-113.

Maslach, C., Schaufeli, W. B. ve Leiter, M. P. (2001). Job burnout. Annual Review of Psychology, 52, 397-422.

May, R. W., Bauer, K. N. ve Fincham, F. D. (2015). School burnout: Diminished academic and cognitive performance. Learning and Individual Differences, 42, 126-131.

Odac1, H., Kalkan, M., Balcı, S. ve Yılmaz, M. (2003). Sosyal beceri eğitiminin ilköğretim öğrencilerinin denetim odağı üzerine etkisi. Türk Psikolojik Danışma ve Rehberlik Dergisi, 2(20), 49-58.

OECD (2015). Education at a Glance. Erişim adresi: http://www.oecd-ilibrary.org/docserver/ download/9615031e.pdf?expires $=1489505356 \& \mathrm{id}=\mathrm{id} \&$ accname=guest\&checksum $=1$ 677DC27766441507FFB9222D3E029C2

Özdemir, E. (2009). Okul yöneticilerinin denetim odaklarına göre tükenmişlik düzeyleri (Yayımlanmamış yüksek lisans tezi). Maltepe Üniversitesi Sosyal Bilimler Enstitüsü, İstanbul.

Öztan, S. (2014). Ortaokul 6.7.8.sını öğrencilerinin okul tükenmişliklerinin yaşam doyumları ve benlik kurgusu algıları açısından incelenmesi (Yayımlanmamış yüksek lisans tezi). İstanbul Arel Üniversitesi Sosyal Bilimler Enstitüsü, İstanbul.

Parker, P. D. ve Salmela-Aro, K. (2011). Developmental processes in school burnout: A comparison of major developmental models. Learning and Individual Differences, 21, 244-248.

Pilkauskaite-Valickiene, R., Zukauskiene, R. ve Raiziene, S. (2011). The role of attachment to school and open classroom climate for discussion on adolescents' school-related burnout. Procedia Social and Behavioral Sciences, 15, 637-641.

Raiziene, S., Pilkauskaite-Valickiene, R. ve Zukauskiene, R. (2014). School burnout and subjective well-being: Evidence from cross-lagged relations in a 1- year longitudinal sample. Procedia Social and Behavioral Sciences, 116, 3254-3258.

Salmela-Aro, K., Kiuru, N. ve Nurmi, J. E. (2008). The role of educational track in adolescents' school burnout: A longitudinal study. British Journal of Educational Psychology, 78, 663-689.

Salmela-Aro, K., Kiuru, N., Pietikäinen, M. ve Jokela, J. (2008). Does school matter? The role of school context in adolescents' school-related burnout. European Psychologist, 13(1), 12-23.

Salmela-Aro, K., Savolainen, H. ve Holopainen, L. (2009). Deppressive symptoms and school burnout during adolescence: Evidence from two cross-lagget longitudinal studies. Journal of Youth and Adolescence, 38(10), 1316-1327.

Salmela-Aro, K. ve Tynkkynen, L. (2012). Gendered pathways in school burnout among adolescents. Journal of Adolescence, 35, 929-939.

Sarıçam, H. (2014). Akademik kontrol odağı ölçeği ergen formunun psikometrik özellikleri. İlköğretim Online, 13(4), 1135-1144. doi.org/10.17051/io.2014.32429

Sardoğan, M. E., Kaygusuz, C. ve Karahan, T. F. (2006). Bir insan ilişkileri beceri eğitimi programının üniversite öğrencilerinin denetim odağı düzeylerine etkisi. Mersin Üniversitesi Eğitim Fakültesi Dergisi, 2(2), 184-194.

Sarıkaya, P. (2007). Tükenmişlik sendromunun kişilik özelliklerinden denetim odağ ile ilişskisi ve bir uygulama (Yayımlanmamış yüksek lisans tezi). Marmara Üniversitesi Sosyal Bilimler Enstitüsü, İstanbul.

Schaufeli, W. (1999). Burnout. J. Firth-Cozens ve R. L. Payne (Yay. haz.), Stress in health Professionals: Psychological and organizational causes and interventions içinde (s. 17-32). New York: Wiley. 
Schaufeli, W. B., Martinez,, M. I., Pinto, A. M., Salanova, M. ve Bakker, A. B. (2002). Burnout and engagement in university students-a cross-national study, MBI-SS. Journal of Cross- Cultural Psychology, 33(5), 464-481.

Schmitz, N., Neumann, W. ve Oppermann, R. (2000). Stress, burnout and locus of control in German nurses. International Journal of Nursing Studies, 37, 95-99.

Seçer, İ. ve Gençdoğan, B. (2012). Ortaöğretim öğrencilerinde okul tükenmişliğinin çeşitli değişkenler açısından incelenmesi. Turkish Journal of Education. 1(2), 1-13.

Sever, M. ve Aypay, A. (2011, Ekim). Ortä̈gretim öğrencilerinde okul tükenmişliğinin bazı değişkenler açısından incelenmesi. XI. Ulusal Psikolojik Danışma ve Rehberlik Kongresi, İzmir.

Slivar, B. (2001). The syndrome of burnout, self-image, and anxiety with grammar school students. Horizons of Psychology, 10(2), 21-32.

Spence, S. H. (1994). Practitioner review: Cognitive therapy with children and adolescents: From theory to practice. Journal of Child Psychology and Psychiatry and Allied Disciplines 35, 1191-1228.

Sürgen, S. (2014). Sinıf öğretmenlerinin denetim odă̆ı ĕgilimleri ile tükenmişlik düzeyleri arasındaki ilişki (Yayımlanmamış yüksek lisans tezi). Balıkesir Üniversitesi Sosyal Bilimler Enstitüsü, Balıkesir.

Sürgevil, O. (2006). Çalışma hayatında tükenmişlik sendromu. Ankara: Nobel Yayınları.

Tümkaya, S. ve Çavuşoğlu, İ. (2010). Sınıf öğretmenliği son sınıf öğretmen adaylarının tükenmişlik düzeylerinin incelenmesi, Ç.Ü. Sosyal Bilimler Enstitüsü Dergisi, 19(2), 468-481.

Wilski, M., Chmielewski, B. ve Tomczak, M. (2015). Work locus of control and burnout in Polish physiotherapists: The mediating effect of coping styles. International Journal Of Occupational Medicine and Environmental Health, 28(5), 875-889.

Yang, H-J. (2004). Factors affecting student burnout and academic achievement in multiple enrollment programs in Taiwan's technical-vocational colleges. International Journal of Educational Development, 24(3), 283-301.

Yeşilyaprak, B. (1990). Denetim odağının belirleyicileri ve değişime ilişkin araştırmalar: Bir eleştirel değerlendirme. Psikoloji Dergisi, 7(25), 41-52.

Yeşilyaprak, B. (2004). Denetim odağı. Y. Kuzgun ve D. Deryakulu (Yay. haz.). Eğitimde Bireysel Farklılıklar içinde (s. 239-258). Ankara: Nobel Yayın Dağıtım.

\section{Extended Abstract \\ Introduction}

In this study, the relationship between school burnout and academic locus of control in adolescents were examined. Within this framework, the answers to these questions were sought: (a) Do adolescents' school burnout sub-dimension scores vary according to demographic variables (school type, sex, grade level, parents' education level, absenteeism, perceived academic achievement and daily regular study duration)? (b) Does academic locus of control predict adolescents' school burnout?

\section{Method}

This study is a relational and quantitative study that used survey model to examine the relationship between school burnout and academic locus of control in high school students. The study was carried out with 701 students selected with stratified sampling from a total of 3511 students going to schools in a province center located in the Central Anatolia region anatolian, vocational and science high schools. $48 \%$ of the students were female and $52 \%$ were male. $27,8 \%$ of the students were in 9th grade, $27,2 \%$ in 10th grade, $26,7 \%$ in 11th grade, and $18,2 \%$ in 12th grade. Secondary School Burnout Scale (SSBS) developed by Aypay (2011) and Academic Locus of Control Scale developed by Akın (2007) were used as data collection tools. 


\section{Result and Discussion}

In this study, the relationship between school burnout and academic locus of control in adolescents was examined. The findings were addressed in three stages. In the first stage, SSBS sub-dimension scores were examined according to demographic variables. Findings showed that there were significant differences in the scores obtained from one or more sub-dimensions of school burnout. One of these findings is differences according to school type. Loss of interest towards school, burnout from studying and burnout from homework sub-dimension scores of science high school students were higher compared to others. Burnout due to family subdimension scores of vocational high school students were higher than others, and exhaustion from teacher attitudes and need to rest and have fun sub-dimension scores of anatolian high school students were higher than others. When sex differences were examined, it was seen that male students' burnout due to family, burnout from doing homework and burnout from teacher attitudes sub-dimension score means were higher, and female students' school inefficacy subdimension scores were higher. This finding is in line with study findings that determined males had more burnout than females (Acar \& Çakır, 2015; Aypay \& Sever, 2015). On the other hand, the current study's findings do not show similarities with studies that did not find any differences in terms of sex (Çapri \& Yedigöz-Sönmez, 2013; Gündüz, 2004). Males' burnout levels being higher in many dimensions compared to females can be explained with gender roles. Behaviors expected by the family and society during the socialization process and exhibition of personality traits put more pressure on males (Çapulcuoğlu \& Gündüz, 2013). Thus, this pressure in areas like school, education and academic achievement may increase school burnout.

In parallel with the literature, in this study, it was found that 9th grade students were the ones who had the least burnout according to grade level (Kutsal, 2009; Kutsal \& Bilge, 2012). It was determined that while the students who were absent for 21-30 days had loss of interest towards school and burnout from studying and doing homework, the students who were absent for 30 days or more were exhausted from teacher attitudes. The students whose mothers were middle school graduates experienced burnout due to family; the students whose parents were high school graduates experienced burnout from doing homework; the students whose fathers were university graduates experienced burnout from studying; and the students whose mothers and father were university graduates experienced school inefficacy. Furthermore, loss of interest towards school, burnout from studying, burnout due to family, burnout from doing homework, exhaustion from teacher attitudes and school inefficacy sub-dimension scores of students who perceived their own academic achievement as low were higher compared to others. The students who perceive their academic achievement as low may be experiencing school burnout due to achievement expectations of people close to them. It was, also, determined that burnout from studying, burnout due to family, exhaustion from teacher attitudes and school inefficacy subdimension scores of students who said they did not study were higher than the others, and burnout from doing homework sub-dimension scores of students who said they study four or more hours were higher than the others. In the second stage of the study, the relationships between variables were examined and a medium level and negative relationship between the school burnout sub-dimensions and internal locus of control, and medium level and positive relationship between the school burnout sub-dimensions and internal locus of control were found. At the same time, internal locus of control negatively and external locus of control positively predicted school burnout. From a theoretical point of view, internally controlled students believe that they have control over their own lives. These individuals believe that the money they earn, the things they do or their physical health are under their control. When they become unhappy in any area of their lives, they believe they can change that with their own effort. On the other hand, externally controlled students are expected to believe that coping with stress is beyond their own strength and capabilities. Thus instead of actively searching for a solution, they are expected to put up with the effects of stress (Yeşilyaprak, 2004). Therefore, burnout is higher in externally controlled individuals compared to internally controlled individuals. Previous researches show that being externally controlled as a personality trait 
poses more risk for experiencing burnout (e. g. Bühler \& Land, 2004; Özdemir, 2009; Sarıkaya, 2007).

According to the current study's results, the 9th graders experience burnout the least, and the higher the grade level is, the higher the burnout level is. Therefore, guidance counselors should carry out individual and group activities to prevent burnout starting from the first grade. In almost all dimensions of school burnout, the scores of students with low number of absentees were low. There can be many reasons (health problems, family, academic anxiety, etc.) for school absenteeism. First of all, these reasons should be determined and works can be done to prevent school absenteeism. In the current study, in all sub-dimensions, it was seen that with the increase in internal control, school burnout decreased and with the increase in external control, the school burnout increased. Locus of control is one of the dimensions of personality. With appropriate conditions and educational opportunities, an individual can go from being externally controlled to being internally controlled (Odac1, Kalkan, Balc1 \& Y1lmaz, 2003; Spence, 1994). For this reason, while school counseling and psychological services plan protective and preventive works regarding student burnout, they should also make psycho-educational works towards developing internal control. 